Diabetologia 6, 392-398 (1970)

\title{
Studies in Prediabetes. \\ Insulin Response to Oral Glucose, Intravenous Tolbutamide and Rapid Intravenous Glucose Infusion in Genetic Prediabetics
}

\author{
M. Serravo-Rios, F. Ramos, J. L. Rodriguez-Miñón and F. Vivatoo \\ Department of Metabolism, Nutrition and Hormones, Instituto de Investigaciones Medicas, \\ Fundación Jimenez-Diaz, Madrid, Spain
}

Received: October 17, 1969

\begin{abstract}
Summary. Twenty-two non-obese genetic prediabetics (offspring with both parents diabetic) were compared with 34 normal volunteers, closely matched by age and weight, in their response to three standardized stimuli: oral glucose tolerance test (with $100 \mathrm{~g}$ of glucose), intravenous tolbutamide tolerance test $(1 \mathrm{~g})$ and rapid intravenous glucose infusion $(0.33 \mathrm{~g} / \mathrm{kg}$ body weight). Blood sugar, immunoreactive insulin and non-esterified fatty acids (N.E.F.A.) were estimated in both groups in the fasting state and at different time intervals during each of the three tests. - Results showed no significant differences (either in carbohydrate tolerance or in the behaviour of the N.E.F.A. levels) between normals and prediabetics at any time in the course of the selected tests. Plasma immunoreactive insulin fasting levels were also closely comparable in both groups, no significantly different insulin release in normals and prediabetics being elicited either by the oral glucose load or by the intravenous tolbutamide injection. However, the rapid intravenous glucose infusion brings about a markedly diminished insulin secretion in the prediabetic group limited to the very early response phase. - Our results strongly support the idea that an impaired ability to secrete insulin under the specific stimulus of the intravenous glucose is a distinguishing feature of the pancreatic beta cell in those humans predisposed to diabetes mellitus.
\end{abstract}

Etude du prédiabète. Réponse de l'insuline au glucose oral, au tolbutamide intraveineux et à la rapide infusion intraveineuse de glucose chez des sujets génétiquement prédiabétiques

Résumé. Vingt-deux sujets non-obèses, génétiquement prédiabétiques (issus de deux parents diabétiques) ont été comparés à 34 sujets normaux de même âge et de même poids, en ce qui concerne leur réponse à trois stimuli standardisés: test de tolérance au glucose oral (avec $100 \mathrm{~g}$ de glucose), test de tolérance au tolbutamide intraveineux $(1 \mathrm{~g})$ et rapide infusion intraveineuse de glucose $(0.33 \mathrm{~g} / \mathrm{kg}$ de poids corporel). La glycémie, l'insuline immunoréactive et les acides gras non-estérifiés (NEFA) ont été mesurés dans les deux groupes à l'état de jeûne et à différents intervalles de temps au cours de chacun des trois tests. - Les résultats n'ont montré de différence significative ni dans la tolérance aux hydrates de carbone, ni dans le comportement des taux de NEFA entre les sujets normaux et les prédiabétiques, à aucun moment au cours des tests choisis. Les taux à jeun d'insuline plasmatique immunoréactive étaient également étroitement comparables dans los deux groupes; ni la charge orale de glucose, ni l'injection intraveineuse de tolbutamide ne provoquait une libération d'insuline significativement dif- férente chez les sujets normaux et les prédiabétiques. Cependant, la rapide infusion intraveineuse de glucose provoquait une sécrétion d'insuline nettement diminuée dans lo groupe prédiabétique qui était plutôt limitée à la phase de réponse très précoce. - Nos résultats confirment fortement l'idée qu'une capacité diminuée à sécréter de l'insuline sous l'influence du stimulus spécifique constitué par la charge brutale de glucose intraveineux est un trait plutôt caractéristique de la cellule bêta pancréatique chez ces sujets qui sont fortement prédisposés au diabète sucré.

Untersuchungen zum Prädiabetes. Insulinausschüttung nach oraler Glucosezufuhr und intravenösen Gaben von Tolbutamid und schnell injizierter Glucose bei genetischen Prödiabetikern

Zusammenfassung. Die Reaktion von 22 normalgewichtigen genetischen Prädiabetikern, deren beide Elternteile Diabetiker waren, wurde mit der von 34 stoffwechselgesunden Freiwilligen entsprechenden. Alters und Gewichtes verglichen. Als standardisierte Stimulationsmethoden dienten: der orale Glucosetoleranztest (100 g Glucose), der i.v. Tolbutamid-Toleranztest (1 g) und die sehnelle i.v. Injektion von $0.33 \mathrm{~g}$ Glucose $/ \mathrm{kg}$ Körpergewicht. Die Spiegel des Blutzuckers, des immunreaktiven Insulins und der unveresterten Fettsëuren (NEFA) wurden bei beiden Gruppen im Nüchternzustand und zu verschiedenen Zeiten während der 3 Tests bestimmt. - Die Resultate zeigten keine signifikanten Unterschiede in bezug auf die Kohlenhydrat-Toleranz und das Verhalten der NEFA zu irgend einem Zeitpunkt der benutzten Tests bei Normalpersonen und. Prädiabetikern. Bei enger Übereinstimmung der Nüchternspiegel des plasma-immunreaktiven Insulins fanden sich auch keine signifikanten Unterschiede in der Ausschüttung nach oraler Glucosegabe oder i.v. Tolbutamidinjektion. Dagegen ergab sich nach schneller i.v. Glucoseinjektion eine deutlich verringerte Insulinfreisetzung bei der Gruppe der Prädiabetiker, die sich jedoch auf die Frühphase beschränkte. - Unsere Resultate sprechen durchaus dafür, daß eine verringerte Kapazität zur Insulinausschüttung nach dem spezifischen Reiz der i.v. Glucosebelastung ein Charakteristikum der Pankreas $\beta$-Zelle der Menschen darstellt, die zum Diabetes mellitus prädisponiert sind.

Key-words: Prediabetic, standard oral glucose tolerance test (OGTT), intravenous tolbutamide test (ITT), rapid intravenous glucose tolerance test (IVGTT), blood sugar, immunoreactive insulin (IRI), non-esterified fatty acids (NEFA), blunted insulin release, early insulin response phase.
Prediabetes is now a well-established term to define the very first phase in the natural history of diabetes mellitus [11], a period in which it is not possible to detect with our present methods any abnormality in glucose homeostasis. It is likely, however, that the earliest consequences of bearing a diabetic gene or 
genes are operating during this prediabetic period. Despite our incomplete knowledge of the mode of transmission of the diabetic trait, it can reasonably be suspected that a prediabetic phase is most probably occurring in human beings under any of these three circumstances: 1 . Monozygotic twins of a diabetic; 2 . offspring of both diabetic parents and 3. women with a peculiar obstetrical history (large babies at birth, recurrent spontaneous abortions etc.).

In recent years, an active investigation has been conducted by several authors on these "natural models of human prediabetes" in a search for any biochemical tracer or tracers specific of the diabetic gene or genes. Many morphological and chemical stigmas have been looked for and described [2], but the pattern of insulin response to different stimuli has been logically enough the most thoroughly explored. Earlier reports using I.L.A. (insulin-like-activity) as a guide to the insulin secretion, claimed that hyperinsulinism was a definite trait of the prediabetic period [25]. Since then, doubts have been thrown upon the reliability of I.L.A. measurements as a true reflection of the physiopathological variations of the endogenous insulin activity [12]. Furthermore, a recent study [10] denies that I.L.A. levels are elevated in prediabetic subjects and ascribes previously reported high values to the concomitant obesity. More specific methods of radio-immunochemical assay of the insulin activity have led to a more accurate characterization of the dynamics of insulin secretion in normal and prediabetic states. Using these techniques a diminished and sluggish insulin release under the stimulus of the intravenously administered glucose has been described by some authors [3] as a distinctive character of the prediabetic subject. This failure in the insulin-releasing mechanism(s) has not been uniformly observed when the oral glucose load. $[13,19,7]$ or the intravenous tolbutamide test $[1,4]$ was selected as the stimulus of the pancreatic beta cell. The implications of these findings in the understanding of the pathogenesis of the diabetes mellitus have been recently discussed by Luft [17].

It is the purpose of this paper to describe our experience in the study of the insulin response to three different stimuli (oral glucose, intravenous tolbutamide and the rapid glucose infusion) of a highly selected group of non-obese genetic prediabetics (offspring of both diabetic parents) with normal tolerance to glucose.

\section{Material and Methods}

Subjects have been divided into two groups: A)Normals and B) Prediabetics. Their characteristics of sex, age and per cent of ideal body weight are summarized in Table 1. Obesity was excluded, subjects in both groups being below the 120 per cent of their ideal body weight (calculated according to the Statistical Bulletin of the Metropolitan Life Insurance Co., 1959).

A) Normal group: Includes 34 volunteer subjects recruited among the auxiliary technical personnel and the medical students of our Institution. Absolute criteria for the selection of this control group were the following: 1. Good general condition with no pathological findings either on clinical examination or in the results of some selected laboratory tests (haemogram, urinanalysis, urine culture, kidney and liver function tests, total lipids and cholesterol, E.C.G. and plain X-ray pictures of the chest and of the abdomen); 2 . Lack of a family history of diabetes mellitus and 3. Normal carbohydrate tolerance judged from the results of the standard oral glucose tolerance test and of the rapid intravenous glucose infusion (see in Methods). The number of determinations performed on subjects of this group during each test is shown in Table 2.

Table 1. Characteristics of sex, age and weight, in normals and prediabetics

\begin{tabular}{lllll}
\hline Groups & $\begin{array}{l}\text { Sex } \\
\text { m. }\end{array}$ & f. & $\begin{array}{l}\text { Age: } \\
\text { years }\end{array}$ & $\begin{array}{l}\text { Ideal } \\
\text { body weighta }\end{array}$ \\
\hline $\begin{array}{lllll}\text { Normals } \\
\text { mean }\end{array}$ & 24 & 10 & $\begin{array}{l}\mathbf{2 6} \\
17-42\end{array}$ & $\begin{array}{l}98 \\
82-114\end{array}$ \\
range & & & & \\
$\begin{array}{l}\text { Prediabetics } \\
\text { mean }\end{array}$ & 11 & 11 & $\begin{array}{l}29 \\
16-43\end{array}$ & $\begin{array}{l}102 \\
86-118\end{array}$ \\
\hline
\end{tabular}

a Based on Statist. Bull. Metrop. Life Insur. Co. 40 Nov.-Dec. 1959 (Documenta Geigy Scientific Tables).

B) Prediabetic group: Comprises 22 subjects, strictly fulfilling the following requirements: 1 . offspring of both diabetic parents; 2 . absolute clinical and analytical normality and 3. normal tolerance to glucose, orally and intravenously administered. Diabetes in the parents was assessed by personal examination in thirteen cases and through a detailed report of the attending physician in the others. In fifteen out of the twenty-two, both parents suffered overt diabetes mellitus for more than 15 years and were currently treated with insulin. In five other prediabetics, the parents had clinical diabetes after 10 years, one member of the couple being under insulin therapy and the other under control with sulphonylureas. The parents of the last two subjects in our series were overt diabetics for more than 10 years and were under control with diet and sulphonylureas. As stated above, the absence of obesity was a prerequisite for inclusion of subjects in any of the two groups.

Table 3 shows the number of determinations made, in the prediabetios in the course of the three tests to be deseribed.

\section{Methods}

General procedure: All the subjects of the prediabetic group were hospitalized throughout the whole period of the experience. Most of the normals were studied on an ambulatory basis, but for the day preceding each test they were admitted to the hospital. Three tests were sequentially done at weekly intervals in every individual; standard oral glucose tolerance test with $100 \mathrm{~g}$ of glucose (O.G.T.T.), intravenous tolbutamide test (I.T.T.) and rapid intravenous glucose tolerance test (I.V.G.T.T.). A diet containing not less than $300 \mathrm{~g}$ of carbohydrate per day was strictly advised during three days before each test, any drug was eventually discontinued and specific prohibition of coffee and smolking made in the $24 \mathrm{~h}$ pre. ceding each test day. All the tests were carried out between 8 and 9 A.M. after a $12 \mathrm{~h}$ fasting period and one hour of resting with the subject recumbent over the whole test time.

O.G.T.T.: Under the previously described conditions a $15 \mathrm{ml}$ fasting blood sample was withdrawn and the sub. 

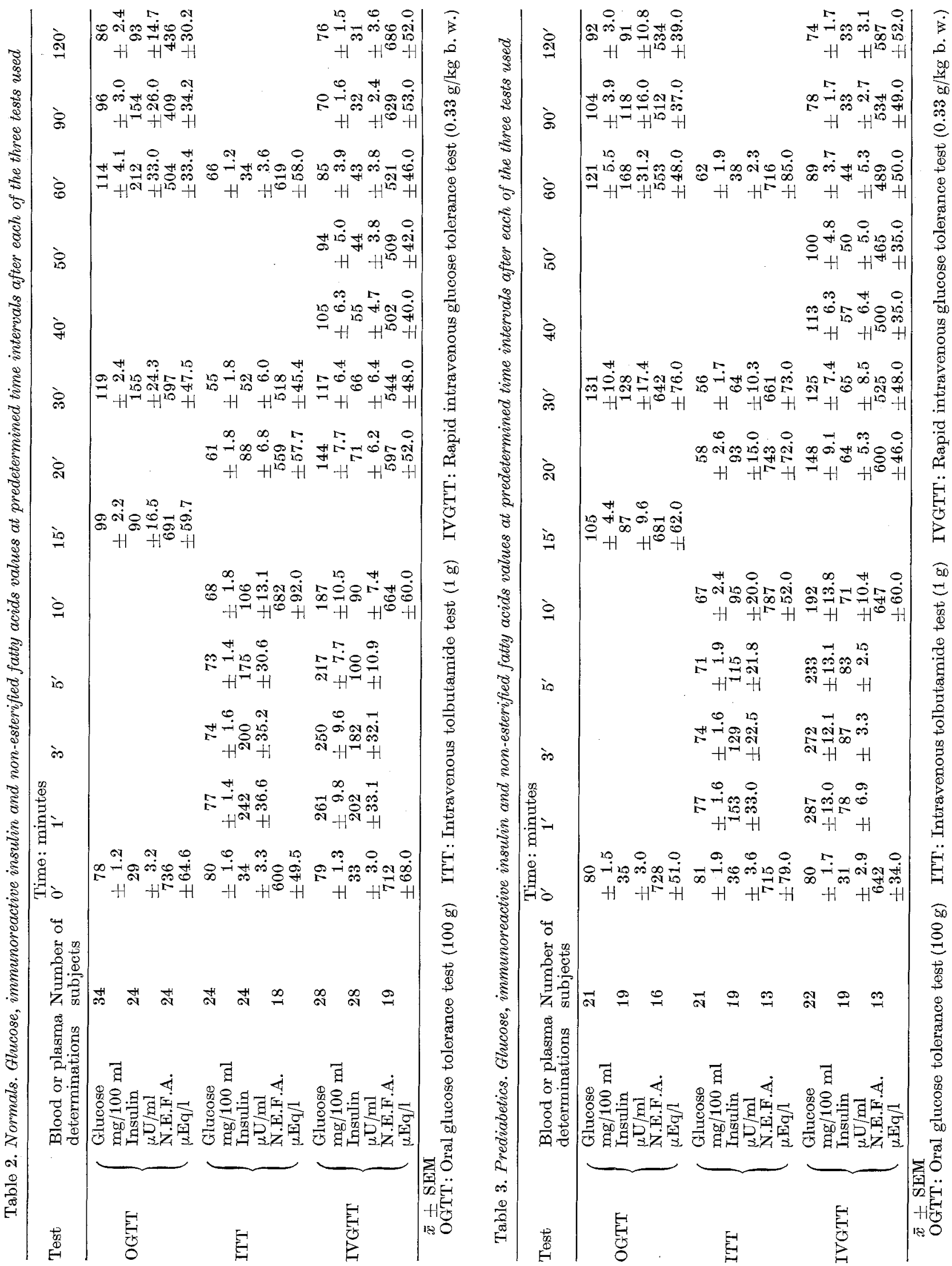
ject was given $100 \mathrm{~g}$ of pure glucose dissolved in $250-$ $300 \mathrm{ml}$ of lemon-flavoured water to drink in $5-6 \mathrm{~min}$. Blood samples $(15 \mathrm{ml}$ each) were obtained at: $15,30,60$, 90 and 120 min after glucose ingestion.

I.T.T.: The morning of the test, an antecubital vein was aseptically catheterized, a $15 \mathrm{ml}$ fasting blood sample obtained and $1 \mathrm{~g}$ of Rastinon Hoechst in $20 \mathrm{ml}$ sterile saline inmediately injected in 3-4 min. Further samples were taken at: $1,3,5,10,20,30$ and 60 min after the tolbutamide injection. Vein patency was assured by a slow infusion of normal saline. Before each sampling, saline infusion was stopped for a minute and disconnected, the first $3-4 \mathrm{ml}$ of blood flowing through the eatheter being discarded in order to avoid a dilution effect.

I.V.G.T.T.: The vein catheterization, maintenance of vein patency and collection of the samples were done as described in the tolbutamide test. After a $15 \mathrm{ml}$ fasting blood sample was withdrawn, a calculated dose of glucose $(0.33 \mathrm{~g}$ per $\mathrm{kg}$ body weight) as a 40 per cent solution was injected in 3-4 min. At the end of the infusion, further blood samples were taken at: $1,3,5,10,20,30$, $40,50,60,90$ and $120 \mathrm{~min}$.

Samples obtained at the predetermined time intervals in each of the three tests were divided into two aliquots, the lesser one being collected in precooled fluoride-oxalatecontaining tubes for glucose determination. The remaining fraction was placed into heparin-containing tubes and inmediately centrifuged. A part of the separated plasma was stored at $4^{\circ} \mathrm{C}$ for determination of non-esterified fatty acids and another aliquot was preserved at $-25^{\circ} \mathrm{C}$ until the assay of the insulin activity was performed.

Evaluation of the tests: The oral glucose tolerance test was interpreted according to the eriteria of Conn and Fajans [9], a normal response being accepted if fasting blood sugar values were at or below $110 \mathrm{mg}$ per cent and the results at 60 and $120 \mathrm{~min}$ after the oral glucose load did not exceed the limits of 160 and $120 \mathrm{mg}$ per cent, respectively. The tolbutamide test was evaluated following the guide-lines of Unger and Madison [28], and the peripheral glucose disappearance rate during the intravenous glucose tolerance test was expressed by the $\mathrm{K}$ values calculated by the semilogarithmic method of Conard [8].

Blood sugar was assayed in duplicate by the photometric method of Hoffman [15] adapted to the Autoanalyzer and the results given in $\mathrm{mg}$ per cent. Non-esterified fatty acids (N.E.F.A.) were estimated in duplicate plasma samples by the titrimetric method of Trout [27] in the $4-6 \mathrm{~h}$ following each test and the results expressed as $\mu \mathrm{Eq} / \mathrm{l}$. Insulin activity as the immunoreactive fraction in plasma was assayed in duplicate by the double antibody method of Hales and Randle [14], the results being given in $\mu \mathrm{U} / \mathrm{ml}$. Insulinogenic reserve was calculated by the Seltzer formula [20]. All the results were statistically studied, and the significance of the differences between mean values in both groups analyzed by the Student's $t$ test.

\section{Results}

Mean values for blood sugar, immunoreactive insulin and N.E.F.A. in both groups during each test are recorded in Tables 2 and 3 . The response patterns of each group of subjects to every specific test are graphically expressed in Figs. 1 (OGTT), 2 (ITT) and 3 (IVGTT).

Blood sugar values: No significant differences either in the fasting blood sugar or in the instantaneous levels of glycaemia at the predetermined time intervals of each test were observed between both groups. According to the criteria adopted both oral glucose tolerance test and intravenous tolbutamide test were well within the normal range in both normals and prediabetics. Peripheral glucose uptake during the rapid intravenous glucose infusion was absolutely normal in both groups, K-values being well above 1.5 . Although in the prediabetics the mean $K$-value $(1.73 \pm 0.21)$ was somewhat lower than in the normals $(1.97 \pm 0.10)$, differences were not statistically significant.

Fatty Acids (N.E.F.A.): The fasting values and the behaviour of the non-esterified fatty acids after each stimulus followed a quite similar pattern in both normals and prediabetics.

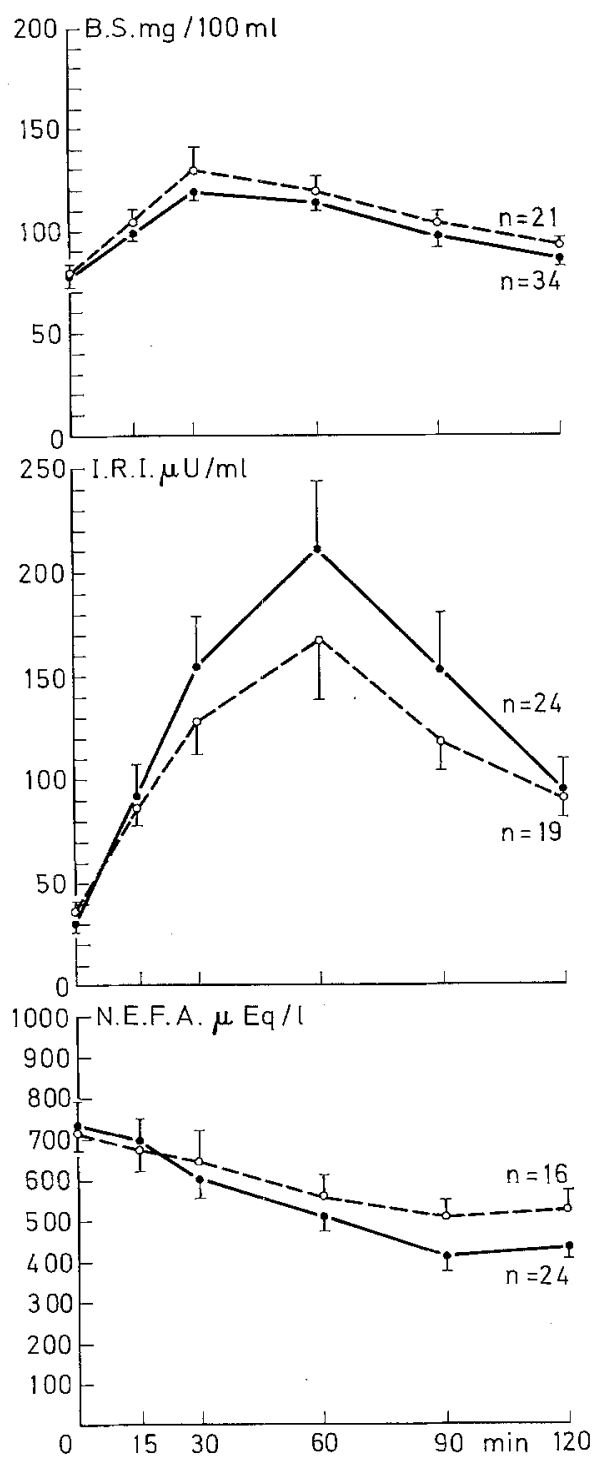

Fig. 1. Oral glucose tolerance test. (O.G.T.T.). B.S. = Blood sugar, $\mathrm{mg} / 100 \mathrm{ml}$; T.R.T. = Immunoreactive insulin $\mu \mathrm{U} / \mathrm{ml}$. N.E.F.A. = Non-esterified fatty acids $\mu \mathrm{Eq} / \mathrm{l}$. 
Immunoreactive insulin (I.R.I.): With almost identical I.R.I. fasting plasma levels, insulin response to oral glucose followed a similar pattern in normals and prediabetics. A maximal I.R.I. peak was reached in both groups at $60 \mathrm{~min}$ followed by a gradual decrease to the $120 \mathrm{~min}$. At this time, however, I.R.I. values were still higher than the fasting ones. Contrariwise to

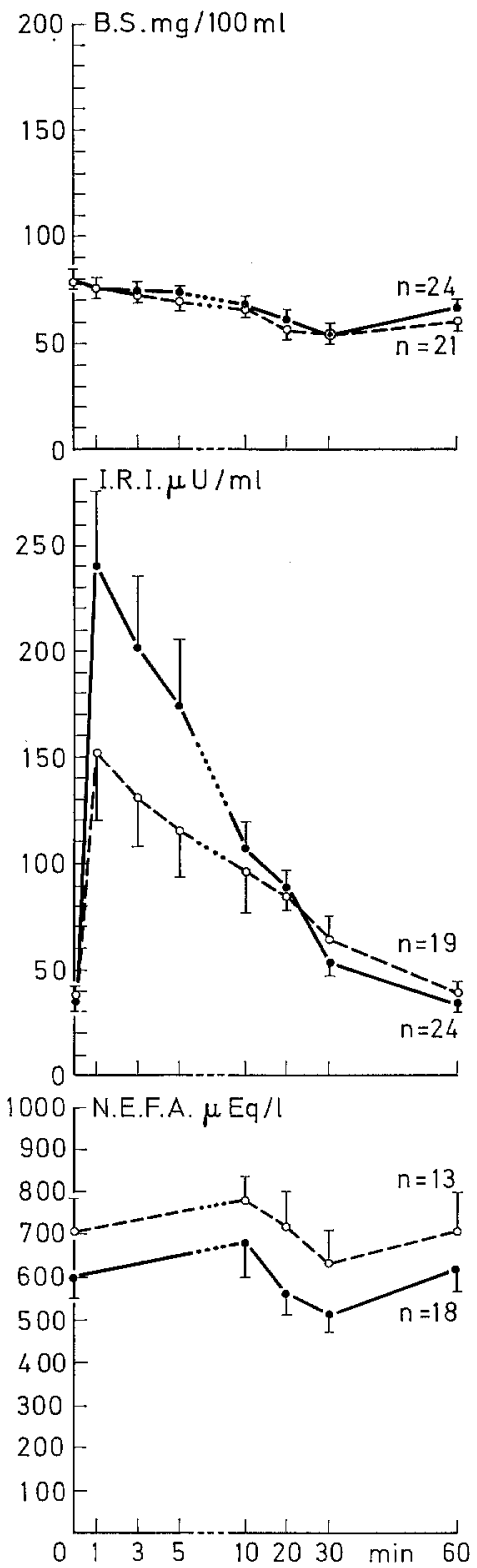

Fig. 2. Intravenous tolbutamide test. (I.T.T.). B.S. = Blood sugar, $\mathrm{mg} / 100 \mathrm{ml}$; I.R.I. = Immunoreactive insulin $\mu$ U/ml; N.E.F.A. = Non-esterified fatty acids $\mu$ Eq/l. Normals - Prediabetics ...... I=SEM

what happens with blood sugar, the insulin curve of the normals overlapped the curve of prediabetics through the test. But here again, differences between mean values in both groups, were not, at any point, statistically significant.
As for the tolbutamide test, injection of the drug induced in both groups an abrupt insulin release with a maximum peak at the first minute, high levels being still maintained at 5 min. Despite the high I.R.I. levels a clear-cut hypoglycaemic effect was not observed until $10 \mathrm{~min}$ after the injection of the drug. Although insulin levels in normals were, at all times,

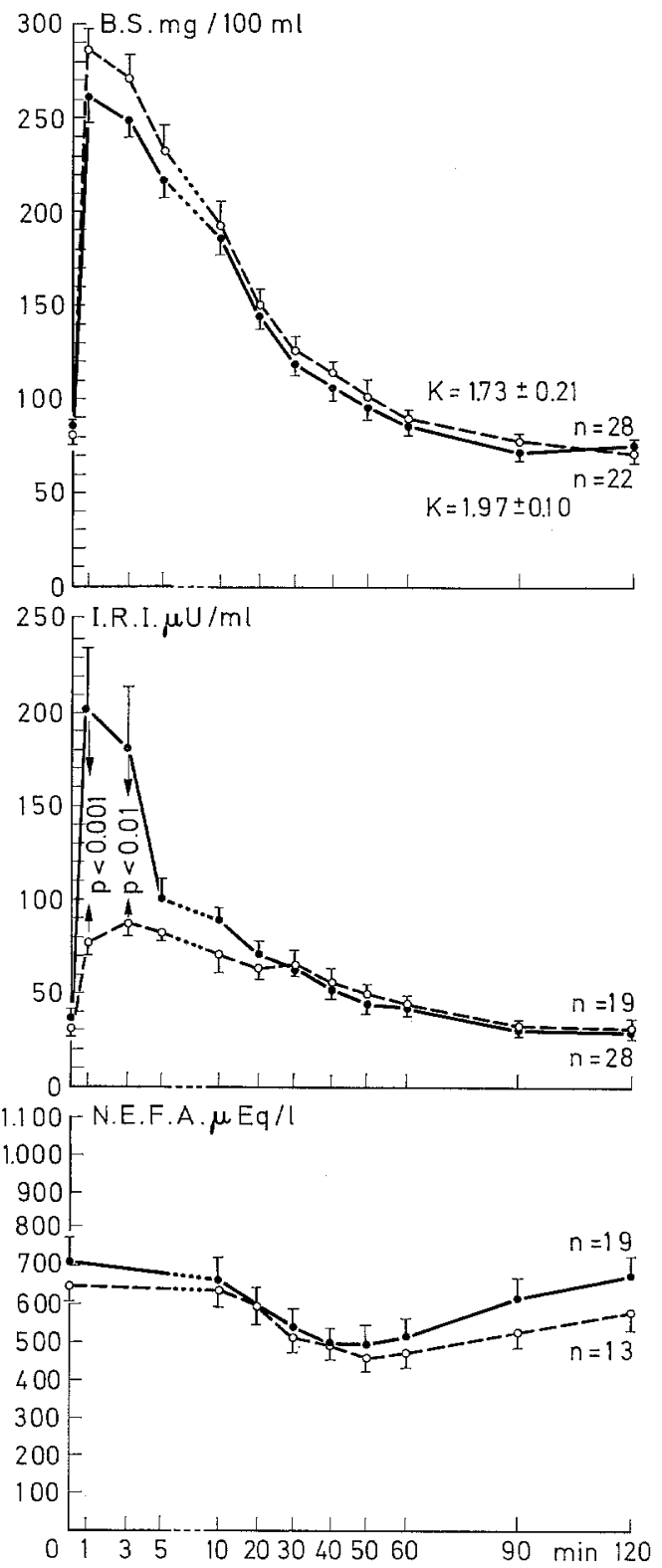

Fig. 3. Rapid intravenous glucose tolerance test. (I.V.G.T.T.). B.S. = Blood sugar, $\mathrm{mg} / 100 \mathrm{ml} ;$ I.R.I. = Immunoreactive insulin $\mu \mathrm{U} / \mathrm{ml}$; N.E.F.A. = Non-esterified fatty acids $\mu \mathrm{Eq} / \mathrm{l}$. Normals

$$
\mathrm{I}=\mathrm{SEM}
$$

higher than those in prediabetics, differences were not statistically significant.

On the other hand, with the rapid intravenous glucose infusion a definite abnormality was readily 
apparent in the very early insulin release phase in the prediabetic group. Subjects in both groups, with almost identical fasting I.R.I. plasma levels, showed an instantaneous insulin release under the intravenous glucose priming with a maximum peak in the first minute. But, whereas the normals had a massive ressponse, a characteristically blunted insulin release was exhibited by the prediabetics, differences between values in both groups being highly significant in the first $(p<0.001)$ and third $(p<0.01)$ minutes.

Table 4. Insulinogenic index $\frac{\Delta I(\mu \mathrm{U} / \mathrm{ml})}{\Delta G(\mathrm{mg} \%)}$ (IVGTT)

\begin{tabular}{lllll}
\hline $\begin{array}{l}\text { Time: } \\
\text { minutes }\end{array}$ & 1 & 3 & 5 & 10 \\
\hline Normals & $0.93 \pm 0.15$ & $0.90 \pm 0.19$ & $0.57 \pm 0.11$ & $0.49 \pm 0.06$ \\
Pre- & $0.26 \pm 0.04$ & $0.31 \pm 0.06$ & $0.32 \pm 0.06$ & $0.47 \pm 0.08$ \\
diabetics & & & & \\
$p$ values & $<0.001$ & $<0.01$ & n.s. & n.s. \\
\hline
\end{tabular}

$\bar{x} \pm$ SEM.

Seltzer's insulinogenic index: After the oral glucose load the insulinogenic reserve at 15 and $30 \mathrm{~min}$ did not significantly differ in both groups. In sharp contrast, the prediabetic group showed a significantly reduced insulinogenic reserve in the first and third minutes after the intravenous glucose infusion compared with the normals (see Table 4).

\section{Discussion}

Our study of 22 non-obese offspring with both parents diabetic shows that the brisk challenge to the beta cell induced by a rapid glucose infusion brings about a clear abnormality of the insulin-releasing mechanism with no apparent derangement in glucose utilization. This finding has been, in fact, the only feature which sharply distinguishes the prediabetics as a "group" from the normal population. Carbohydrate tolerance tested by the oral load with $100 \mathrm{~g}$ of glucose failed to discriminate between both groups. A similar conclusion has recently been obtained by Siperstein et al. [22] in 30 prediabetic subjects, using essentially the same criteria to evaluate the oral glucose tolerance test. Furthermore, when the tolerance to glucose was explored by the intravenous route fairly normal K-values emerged from our prediabetic group, differences with those in the normals being non-significant. Thus we were not able to confirm previously reported results $[19,26,18]$ claiming that the prediabetic population maintained a normal glucose homeostasis at higher levels of glycaemia than those of the normal subjects. Also, the hypoglycaemic effect experienced by subjects in both groups after the injection of tolbutamide was closely similar, the lowest blood sugar levels being attained at $30 \mathrm{~min}$.

As for lipid metabolism, we have been unable to confirm the high fasting values and the delayed de- crease of N.E.F.A. levels after the glucose infusion previously reported by Camerini-Davalos et al. [2], and more recently by Daweke et al. [10] and Soeldner et al. [24]. In close agreement with the experience of Boden et al. [1], in our prediabeties the N.E.F.A. fasting values and their behaviour during the stimuli used did not exhibit any significant change when compared with the normals.

Insulin values in the fasting state and after any of the stimuli described, in normals as well as in prediabetics were, in our hands, higher than those usually given in the literature. Although no satisfactory explanation exists for this fact, Jörgensen has recently commented upon the extremely wide range of normal insulin values found by several authors using essentially the same double antibody technique for insulin assay [16]. Our figures are intermediate between those published by Daweke [10] and those of Cerasi and Luft [5].

Insulin secretion after oral glucose load was rather similar in the two groups of subjects. With this test, there was no indication of a sluggish insulin release or of a quantitative reduction as reported by some authors $[10,7]$ in prediabetics. Again, after the injection of tolbutamide insulin secretion curve was closely parallel in normals and prediabetics in close agreement with the results reported by Boden et al. [1] in 13 prediabetic males. On the other hand, the rapid intravenous glucose infusion unequivocally elicited in the prediabetics a markedly decreased insulin release in the first and third minutes after the stimulus. Though some individual scattering in I.R.I. levels was present, only 5 out of 19 prediabeties reached I.R.I. values over $100 \mu \mathrm{U} / \mathrm{ml}$ in the first and third minute after intravenous glucose, whereas in the normal group only 8 out of 28 were below this limit in the same time intervals. Analysis of the insulinogenic reserve using the Seltzer's formula also showed a diminished insulin reserve in the prediabetic subjects at the first and third minute after intravenous glucose priming. So, as recently stated by Simpson et al. [21], our experience confirms that this characteristic reduction of the insulin secretion in the prediabetics is typically restricted to the very early release phase. Our results are, indeed, basically in agreement with those obtained by Cerasi and Luft [3] in monozygotic twins of diabetics under continuous glucose perfusion and by Soeldner et al. [23] in young genetic prediabetics, also after the rapid intravenous glucose injection. But, in contrast to the experience of these authors we could not substantiate a decreased insulin release by the prediabetics longer than the third minute after the intravenously administered glucose.

It might then be concluded that when obesity is carefully excluded, the so-called genetic prediabetics do not show either a significant carbohydrate abnormality or any disturbance in the metabolism of the non-esterified fatty acids when compared with a normal population closely matched by age and weight. But a 
quite subtle anomaly in the insulin-releasing mechanism(s) does exist in the prediabetic group, and the rapid intravenous glucose tolerance test is - in our experience - the only adequate stimulus to uncover this latent inability, whereas other provocative tests (oral glucose and intravenous tolbutamide) are completely uneffective. The meaning of this peculiar lowering of the insulinogenic reserve in prediabetics is still rather obscure. Quite recently, however, Cerasi and Luft [6] have presented sound experimental evidence suggesting that the biochemical defect underlying the anomalous insulin secretion which characterizes the prediabetic period might be due to a decrease in the levels of the $3^{\prime}-5^{\prime}$ cyclic AMP in the beta cell.

Acknowledgements. The authors wish to express their thanks to the Novo Industri, Copenhagen, for the supply of glucagon-free pig insulin (through the kindness of Dr. V. Arias Paz) and to the Hoechst Laboratories for the supply of Rastinon. The excellent technical assistance of Drs. J. Gonzalez-Villasante and I. Muñoz Baroja is also gratefully appreciated.

\section{References}

1. Boden, G., Soeldner, J.S., Gleason, R. E., Marble, A.: Elevated serum growth hormone and decreased serum insulin in prediabetic males after intravenous tolbutamide and glucose. J. elin. Invest. 47, 729-739 (1968).

2. Camerini-Davalos, R.A., Caulfield, J.B., Rees, S.B., Lozano-Castañeda, O., Naldjian, S., Marble, A.: Preliminary observations on subjects with prediabetes. Diabetes 12, 508-518 (1963).

3. Cerasi, E., Luft, R.: Insulin response to glucose infusion in diabetic and non-diabetic monozygotic twin pair: Genetic control of insulin response ? Acta endocr. (Kbh.) 55, 330-345 (1967).

4. - - Further studies on healthy subjects with low and high insulin response to glucose infusion. Acta endocr. (Klbh.) 55, 305-329 (1967).

5. - - The plasma insulin response to glucose infusion in healthy subjects and in diabetes mellitus. Acta endocr. (Kbh) 55, 278-304 (1967).

6. - - Modification de l'insulino-sécrétion par la théophylline et l'hormone de croissance chez le sujet prédiabétique. In: Journées de Diabetologie, Hôtel Dieu, 29-31 Mai, 1969; pp. 236-239. Paris: Editions Medicales Flammarion 1969.

7. Colwell, J.A., Lein, A.: Diminished insulin response to hyperglycemia in Prediabetes and Diabetes. Diabetes 16, 560 - 565 (1967).

8. Conard, V.: Franckson, I.R.M., Bastinie, P.A., Kestens, J., Kóvacs, L.: Etude critique du triangle d'hyperglycemie intraveineux chez l'homme normal et determination d'un "coefficient d'assimilation glucidique". Arch. int. Pharmacodyn. 13, 277-292 (1953).

9. Conn, J.W., Fajans, S.S.: The prediabetic state. A concept of dynamic resistance to a genetic diabetogenic influence. Amer. J. Med. 31, 839 - 850 (1961).

10. Daweke, H., Ruenauver, R., Schilling, W., Günklee, D., Jahnke, K., Liebermeister, H., Gries, F.A., Oberdisse, K.: Untersuchungen des Kohlenhydrat und Fettstoffwechsels bei Prädiabetes. Diabetologia 4, $349-357$ (1968).

11. Fajans, S.S., Conn, J.W.: Prediabetes. Subclinical diabetes and latent Chemical Diabetes. Interpretation, Diagnosis and Treatment. In: "On the Nature and Treatment of Diabetes Mellitus". Chapter 46, pp. 641-656. Editors: Leibel, B.S., Wrenshall, G.A.,
Amsterdam, New York: Excerpta Medica Foundation 1965.

12. Froesch, E.R.: Insulin-like activity in blood. In: Clinical Endocrinology. Part II, pp. 422-433. Eds. Astwood, E.B., Cassidy, C.E. New York, London: Grune Stratton. 1968.

13. Grodsky, G.M., Karam, J.H., Pavlatos, F.Ch., Forsham, P.H.: Serum insulin response to glucose in prediabetic subjects. Lancet 1965 I, 290-291.

14. Hales, C.N., Randle, P.J.: Immunoassay of insulin with insulin-antibody precipitate. Biochem. J. 88, $137-146$ (1963).

15. Hoffmann, W.S.: A rapid photoelectric method for the determination of glucose in blood and urine. $J$. biol. Chem. 120, $51-55$ (1937).

16. Jörgensen, K.R.: Evaluation of the double antibody radioimmunoassay of insulin and the determination of insulin in plasma and urine in normal subjects. Acta endocr. (Kbh.) 60, 327-351 (1969).

17. Luft, R.: Some considerations on the pathogenesis of Diabetes mellitus. New Engl. J. Med. 279, 10861092 (1968).

18. Pyke, D.A., Taylor, K.W.: Glucose tolerance and serum insulin in unaffected identical twins of diabetics. Brit. med. J. 1967 II, 21-22.

19. Ricketts, H.T., Cherry, R.A., Kirsteins, L.: Biochemical studies of prediabetes and Diabetes. Diabetes $\mathbf{1 5}, 880-888$ (1966).

20. Seltzer, H.S., Smith, W.L.: Plasma insulin activity after glucose. An index of insulinogenic reserve in normal and diabetic men. Diabetes 8, 417-424 (1959).

21. Simpson, R.G., Benedetti, A., Grodsky, G.IM., Karam, J.H., Forsham, P.H. : Early phase of insulin release. Diabetes 17, 684-692 (1968).

22. Siperstein, M.D., Unger, R.H., Madison, L.L.: Studies of muscle capillary basement membranes in Normal Subjects, Diabetic and Prediabetic patients. J. clin. Invest. 47, 1973-1999 (1968).

23. Soeldner, J.S., Gleason, R.E., Rojas, L., Kahn, C.B., Marble, A.: Serum insulin and serum insulin-blood glucose relationships in genetic prediabetic Males with normal glucose tolerance. In: "Diabetes". Proceedings of the sixth Congress of the International Diabetes Federation. Stockholm, Sweden. July, 30, August, 4, 1967, pp. 505-514. Ed. by Östman and Milner R.D.G. Amsterdam: Excerpta Medica Foundation 1969.

24. - - Williams, R.F., Garcia, M.J., Beardwood, M.D., Marble A. : Diminished serum insulin response to glucose in genetic prediabetic males with normal glucose tolerance. Diabetes 17, 17-26 (1968).

25. Steinke, J., Soeldner, J.S., Damerini-Dávalos, R.A., Renold, A.E.: Studies on serum-like activity (I.L.A.) in prediabetes and early overt diabetes. Diabetes 12, $501-506(1963)$.

26. Taton, J., Pometta, D., Camerini-Dávalos, R.A., Marble, A.: Genetic determinism to Diabetes and tolerance to glucose. Lancet 1964 I, $1360-1362$.

27. Trout, D.L., Estes, E.H., Jr., Friedberg, S.J.: Titration of free fatty acids of plasma: A study of eurrent method and a new modification J. Lipid Res. 1, 199-201 (1960).

28. Unger, R.H., Madison, L.L. : A new diagnostic procedure for mild diabetes mellitus: Evaluation of an intravenous tolbutamide response test. Diabetes 7, $455-461(1958)$.

Dr. J.L. Rodriguez-Minôn

Jefe Clinico deI Departamento

de Nutrición y Endocrinologia de la

Clinica de la Concepción

Monte Esquinza 20

Madrid 4, Spain 